\title{
UPAYA MENINGKATKAN PEMAHAMAN PERENCANAAN KARIR MELALUI LAYANAN INFORMASI KARIR MENGGUNAKAN APLIKASI GOOGLE CLASSROOM SISWA KELAS XII MIPA 3 SMA NEGERI 1 TARAKAN TAHUN AJARAN 2020/2021
}

\author{
Sri Utami \\ SMA Negeri 1 Tarakan \\ Email: utamiakma@gmail.com
}

\begin{abstract}
This research aims to Improve Understanding of Career Planning through Career Information Services Using Google Classroom Media Students of Grade XII MIPA 3 SMA Negeri 1 Tarakan. This type of research is a research action counseling guidance, the research subjects are students of class XII MIPA as much as 36 person. Data collection techniques are obtained through observation and the results of understanding career planning obtained from initial tests and tests at each end of the meeting. This research consists of two cycles, namely cycle I consists of 3 meetings and cycle II which also consists of 3 meetings. Analyze data using descriptive analysis. The data obtained at each observation activity of each cycle, analyzed descriptively using percentage techniques to see the trends that occur in the service process. The results showed that career information services can improve understanding of students' career planning and have a positive impact. This can be seen from the better understanding of students towards career planning through career information services. This is evidenced by the increase in teacher and student activity obtained through observation sheets by $89.9 \%$, understanding of career planning also increased from cycle I to cycle II, namely each in cycle I of the first meeting only 17 students or $47.2 \%$ had an understanding and in cycle II the sixth meeting increased to 33 students or $88.9 \%$ had classical understanding and the average student results increased from the average cycle I of the first meeting 6.3 increased in the second cycle of the sixth meeting to 10 so as to exceed the criteria of individual career planning, namely a score of 7-12.The results of this study can be used as a
\end{abstract}

\begin{abstract}
Abstrak
Penelitian ini bertujuan untuk Meningkatkan Pemahaman Perencanaan Karir melalui Layanan Informasi Karir Menggunakan Media Google Classroom Siswa Kelas XII MIPA 3 SMA Negeri 1 Tarakan. Jenis penelitian ini adalah penelitian tindakan bimbingan konseling, subjek penelitian adalah peserta didik kelas XII MIPA sebanyak 36 orang. Teknik pengumpulan data diperoleh melalui observasi dan hasil pemahaman perencanaan karir yang diperoleh dari tes awal dan tes disetiap akhir pertemuan. Penelitian ini terdiri dari dua siklus, yaitu siklus I terdiri dari 3 kali pertemuan dan siklus II yang juga terdiri dari 3 kali pertemuan. Analisis data menggunakan analisis deskriptif. Data yang diperoleh pada setiap kegiatan observasi dari setiap siklus, dianalisis secara deskriptif menggunakan teknik persentase untuk melihat kecenderungan yang terjadi dalam proses layanan. Hasil penelitian menunjukkan bahwa layanan informasi karir dapat meningkatkan pemahaman perencanaan karir siswa dan memberikan dampak positif. Hal ini dapat dilihat dari semakin baiknya pemahaman siswa terhadap perencanaan karir melalui layanan informasi karir. Hal ini dibuktikan dengan adanya peningkatan aktivitas guru dan siswa yang diperoleh melalui lembar observasi sebesar $89,9 \%$, pemahaman perencanaan karir pun meningkat dari siklus I hingga siklus II yaitu masing-masing pada siklus I pertemuan pertama hanya 17 orang siswa atau 47,2\% saja yang memiliki pemahaman dan pada siklus II pertemuan keenam meningkat menjadi 33 orang siswa
\end{abstract}


atau $88,9 \%$ memiliki pemahaman secara klasikal serta rata-rata hasil siswapun meningkat dari rata-rata siklus I pertemuan pertama 6,3 meningkat pada siklus II pertemuan keenam menjadi 10 sehingga melampaui kriteria perencanaan karir secara individu yaitu skor 712. Hasil penelitian ini dapat dijadikan rujukan bagi guru bimbingan konseling dalam penyusunan program dan penerapan layanan informasi karir menggunakan aplikasi google classroom dalam rangka meningkatkan pemahaman perencanaan karir siswa terutama dimasa pandemic.

Keywords : understanding career planning, career information services, google classroom applications

\section{PENDAHULUAN}

Pelayanan bimbingan dan konseling (BK) merupakan bagian integral dari proses pendidikan pada satuan pendidikan. Sebagai bagian integral dari proses pendidikan, bimbingan konseling merupakan upaya memfasilitasi dan memandirikan siswa dalam rangka mencapai perkembangan yang utuh dan optimal.

Bimbingan dan konseling pada satuan pendidikan mencakup empat bidang layanan, yaitu bidang layanan yang memfasilitasi perkembangan pribadi, sosial, belajar dan karir. Pada hakikatnya empat bidang layanan tersebut merupakan satu kesatuan utuh yang tidak dapat dipisahkan dalam setiap diri individu siswa.

Salah satu permasalahan yang menarik penulis untuk diteliti adalah bidang karir. Bimbingan karir selain memberikan respon pada masalah-masalah yang dialami siswa, juga bertujuan untuk membantu siswa memperoleh pengetahuan, sikap, dan ketrampilan dalam pekerjaan. Selain itu, bimbingan karir menitikberatkan pada perencanaan kehidupan seseorang dengan mempertimbangkan keadaan individu dengan lingkungan agar dapat memperoleh pandangan positif ke depan. Dengan demikian, bimbingan karir berperan penting dalam meningkatkan perencanaan karir siswa.

Siswa SMA berkisar pada rentang usia 15-18 tahun yang dalam masa ini tergolong dalam rentang usia remaja. Remaja sebagai individu yang sedang mengalami proses peralihan baik itu menyangkut pertumbuhan maupun psikologis yang berkembang pesat, memiliki tugas-tugas perkembangan yang mengarah pada kesiapan memenuhi tuntutan dan harapan peran sebagai orang dewasa. Salah satu tugas perkembangan yang harus dicapai siswa SMA yaitu memilih dan mempersiapkan karir

Pada tingkat SMA pemilihan karir sudah seharusnya ditumbuhkan bahkan sudah harus dimatangkan. Salah satu kunci sukses dalam berkarir adalah perencanaan yang matang. Layanan informasi karir adalah kegiatan dan layanan bantuan yang diselenggarakan guru bimbingan dan konseling di sekolah kepada siswa dengan tujuan untuk memperoleh penyesuaian diri, pemahaman tentang pendidikan lanjutan dan pemahaman tentang dunia kerja. Peranan layanan informasi karir di sekolah sangatlah penting. Dalam perkembangan karir, permasalahan karir akan menjadi salah satu masalah utama yang perlu diperhatikan dalam merancang masa depan siswa nantinya.

Suksesnya pencapaian karir seseorang dipengaruhi oleh adanya kemampuan perencanaan karir dan pengambilan keputusan yang matang. Seseorang yang memiliki kemampuan perencanaan karir tentunya mampu memahami dirinya. Dengan demikian, individu tersebut dapat memutuskan pilihan yang paling tepat sesuai dengan keadaan dirinya.

Perencanaan karir merupakan proses pencapaian tujuan karir individu, yang ditandai dengan adanya tujuan yang jelas setelah menyelesaikan pendidikan, cita-cita yang jelas terhadap pekerjaan, dorongan untuk maju dalam bidang pendidikan dan pekerjaan yang di cita-citakan, persepsi yang realistis terhadap diri dan lingkungan, 
kemampuan mengelompokkan pekerjaan yang diminati, memberikan penghargaan yang positif terhadap pekerjaan dan nilainilai, kemandirian dalam proses mengambil keputusan, kematangan dalam hal mengambil keputusan, dan menunjukkan cara-cara realistis dalam mencapai cita-cita pekerjaan.

Tidak sedikit dari siswa SMA yang masih bingung dalam merencanakan karir setelah lulus SMA. Seperti yang terjadi pada siswa SMA Negeri 1 Tarakan. Minat siswa untuk melanjutkan keperguruan tinggi sangat baik. Namun, ketika ditanya "ingin mengambil jurusan apa?, ingin kuliah dimana? akan bekerja dimana dan menjadi apa ?" mereka masih kebingungan dan tidak memiliki arah yang pasti. Mereka hanya mengandalkan keterampilan seadanya dengan pengetahuan tentang dunia kerja dan perguruan tinggi yang minim.

Selain itu, sebelum pandemi banyak siswa yang datang baik secara perorangan atau kelompok untuk konsultasi mengenai karir, namun dengan kondisi pandemi saat ini menimbulkan kesulitan bagi siswa karena tidak bisa melakukan konsultasi secara langsung, sehingga dengan melaksanakan layanan informasi karir menggunakan google classroom diharapkan informasi mengenai perencanaan karir dapat tersampaikan dengan efektif dan kesulitan-kesulitan untuk mengambil keputusan karir akan dapat dihindari manakala siswa memiliki sejumlah informasi yang memadai tentang hal hal yang berhubungan dengan karir.

Untuk itulah, mereka harus mendapatkan layanan informasi karir guna memperoleh pemahaman yang memadai tentang berbagai kondisi karakteristik dirinya, baik tentang bakat, minat, cita-cita berbagai kekuatan serta kelemahan yang ada dalam dirinya. Dalam hal ini, tentunya tidak cukup hanya memahami diri. Namun juga harus memahami kondisi yang ada di lingkungannya, seperti kondisi pasar kerja, persyaratan, jenis pekerjaan, prospek pekerjaan serta hal-hal lainnya yang berhubungan dengan dunia kerja. Sehingga pada kesempatannya siswa dapat mengambil keputusan yang terbaik sesuai dengan keadaan dirinya.

Melalui layanan informasi karir diharapkan karir yang dipilih siswa sesuai dengan bakat, minat dan nilai-nilai yang di junjung tinggi. Jika memperoleh karir yang tepat, maka hidup akan bahagia. Dan kebahagiaan adalah tujuan hidup semua orang. Oleh sebab itu layanan informasi karir sangat dibutuhan diranah pendidikan. Berdasarkan masalah diatas maka penulis tertarik untuk mengadakan penelitian tentang perencanaan karir siswa, dengan judul penelitian " Upaya Meningkatkan Pemahaman Perencanaan Karir Melalui Layanan Informasi karir Menggunakan Aplikasi Google Classroom Kelas XII MIPA 3 SMA Negeri 1 Tarakan Tahun 2020/2021".

\section{KAJIAN LITERATUR Perencanaan Karir}

Perencanaan karir merupakan sesuatu yang menyangkut masa depan dalam jangka panjang yang harus direncanakan sejak jauh hari. Frank Parson dalam Winkel \& Hastuti (2010:408), menyatakan perencanaan karir yaitu suatu cara untuk membantu siswa dalam memilih suatu bidang karir yang sesuai dengan potensi mereka, sehingga dapat cukup berhasil di bidang pekerjaan. Perencanaan karir perlu disiapkan sebelum siswa terjun secara langsung dalam dunia karir. Perencanaan karir didasarkan atas potensi yang dimiliki siswa sehingga tidak ada pertentangan antara karir yang dipilih dengan potensi yang ada pada diri siswa.

Simamora (2011:504) menyatakan bahwa perencanaan karir (career planning) adalah suatu proses dimana individu dapat mengidentifikasi dan mengambil langkahlangkah untuk mencapai tujuan- tujuan karir. Perencanaan karir melibatkan pengidentifikasian tujuan- tujuan yang berkaitan dengan karir dan penyusunan rencana-rencana untuk mencapai tujuan tersebut. Dalam proses perencanaan karir 
individu akan memperoleh pengetahuan tentang potensi yang ada pada diri yang meliputi keterampilan, minat, pengetahuan, motivasi, dan karakteristik yang digunakan sebagai dasar dalam pemilihan karir yang kemudian dilanjutkan dengan menentukan tahapan untuk bisa mencapai karir yang sudah dipilih.

Dillard (1987) menyatakan bahwa terdapat empat tujuan dari perencanaan karir, yaitu : a) Memperoleh kesadaran dan pemahaman diri (acquiring self awreness). Penilaian kekuatan dan kelemahan individu merupakan langkah penting dalam perencanaan karir. Salah satu penilaian memungkinkan individu untuk lebih memahami diri sendiri yang berhubungan dengan tujuan dan rencana karir. Pengetahuan untuk perencanaan karir dapat menghindari dari ketidakpuasan, kekecewaan, dan ketidakbahagiaan melalui kesadaran diri yang akurat. b)Mencapai kepuasan pribadi. Individu mungkin lebih suka dalam kegiatan karir yang mirip dengan minat individu atau yang memberikan perasaan emosional dan atau kesenangan fisik. Untuk memperoleh kepuasan dari pekerjaan, individu harus memahami persyaratan karir dan mengenali minat

beserta

keinginannya.c. Mempersiapkan diri untuk memperoleh penempatan dan penghasilan yang sesuai (preparing for adequate placement).Individu yang akan mencari pekerjaan harus dirancang secara khusus selama perencanaan karir. Individu mungkin ingin menghindari daerah daerah yang memberikan peluang terbatas atau tidak sesuai dengan minatnya. Pendekatan seperti ini akan membantu individu menemukan karir, jenis karir dan menerima karir. d) Efisien usaha dan penggunaan waktu ( efficiently using time and affort).Tujuan lain perencanaan karir adalah untuk memungkinkan individu untuk secara sistematis memilih karir. Individu dapat menggunakan waktu secara efisien untuk mempelajari diri sendiri dalam kaitanya dengan berbagai pilihan karir. Umumnya orang orang yang telah berpartisipasi dalam perencanaan karir lebih puas dengan karir mereka dan tetap aktif bekerja lebih lama dari pada mereka yang tidak melakukan perencanaan karir.

Perencanaan karir individu menurut Zlate dalam Antoniu (2010 : 16) dapat ditelusuri melalui lima langkah: 1) Self assessment (penilaian diri) adalah kumpulan informasi tentang diri individu (nilai-nilai, minat, keterampilan), penilaian berkelanjutan dan penilaian orang lain. 2) Exploring opportunities (mencari peluang kesempatan) melibatkan pengumpulan informasi tentang ada kesempatan di dalam atau di luar organisasi dan lembaga (pelatihan dan pengembangan metode lainnya). 3) Making decisions and setting goals (pembuatan keputusan dan penetapan tujuan) pembuatan tujuan pada jangka pendek dan jangka panjang, untuk pelatihan persyaratan, perubahan pekerjaan / departemen dll. 4) Planning (perencanaan) terdiri dari menentukan cara dan sarana untuk mencapai tujuan, mengharuskan individu untuk mencapai tujuannya, mempertimbangkan konsekuensinya, pengaturan tempat waktu dan persyaratan sumber daya. 5) Pursuit of achievement (mengejar tujuan prestasi), tindakan oleh individu untuk keberhasilan dan kegagalan dan membuat keputusan untuk mempertahankan atau mengubah arah karir.

Manfaat perencanaan karir , menurut Dewa Ketut Sukardi (1993:24-25) yaitu membantu individu untuk :1) Mempersiapkan pengambilan keputusan yaitu individu mengetahui keputusan penting tindakan apa yang individu akan laksanakan selanjutnya, mampukah individu untuk melihat macam-macam informasi yang individu perlukan dalam hubungannya untuk mengambil suatu keputusan.2) Mengembangkan beberapa kepercayaan dalam diri individu sendiri yaitu ketika individu mengetahui apa yang individu kehendaki dari kehidupan ini dan apakah yang individu lakukan, individu akan merasa lebih aman menelusurinya daripada yang individu kehendaki. Jika 
individu baru saja melangkah melintasinya, untuk memahami hal ini individu perlu untuk memikirkan tentang axietas yang disebabkan oleh orang tua individu, teman-teman individu dan orang lainnya. Kenapa mereka berkata : "apakah kamu akan bermaksud bekerja setelah menyelesaikan sekolah?" 3) Menemukan beberapa makna dari akitivitas individu sekarang, contohnya jika individu menyadari bahwa ilmu kimia penting untuk individu ikuti sebagai lapangan kerja seterusnya individu akan banyak menghabiskan waktu untuk mempelajari matapelajaran kimia, daripada sebaliknya. 4) Memberikan ketenangan bagi diri individu untuk mengenal kesempatankesempatan yang baik yang dijumpainya yaitu untuk menggambarkan hal ini misalnya individu telah menetapkan menjadi seorang pilot. Tindak lanjut dari penetapan ini beberapa kesempatan mungkin timbul, kesempatan untuk membaca buku-buku tertentu mengenai pesawat udara, menemukan seorang yang sudah cukup lama menjadi seorang pilot, siapa saja yang mengetahui seluk beluk pesawat. 5) Menentukan apa yang seharusnya individu dapat lakukan sekarang dalam kaitannya dengan apa yang ingin individu capai dan inginkan. Contoh, jika individu bermaksud untuk menjadi seorang pianis, individu mungkin berusaha menyempurnakan teknik individu dengan mengadakan latihan-latihan. Individu dapat bekerja secara part-time dalam hubungannya untuk memperoleh uang untuk biaya training selanjutnya. Individu dapat melibatkan diri dan ikut serta bermain pada sekolah atau kursus musik dalam kaitannya untuk mendapatkan kepercayaan diri dalam pertunjukan selanjutnya. 6) Menemukan apa yang harus individu persiapkan pada setiap tahap baru dalam hidup anda selama individu bertumbuh dan berkembang sampai lebih matang, individu akan berubah yaitu keadaan individu berubah dengan mengetahui lebih dini apa yang akan terjadi, individu akan mengambilnya dengan tepat, individu akan mampu untuk mengadakan, memelihara, mempertahankan dengan kontinyu penyesuaian diri individu sendiri dan bermacam-macam fakta kehidupan dan dunia kerja. Individu juga akan berada dalam posisi yang terbaik untuk memperoleh beberapa pilihan secara terbuka selama individu bergerak maju melewati dan menjelajahi kehidupan individu.

\section{Layanan Informasi Karir}

Layanan informasi adalah layanan Bimbingan dan Konseling yang memungkinkan siswa (klien) menerima dan memahami berbagai informasi (seperti informasi pendidikan dan informasi jabatan) yang dapat digunakan sebagai bahan pertimbangan dan pengambilan keputusan untuk kepentingan klien.

Sukardi (2004 : 44) mengemukakan bahwa layanan informasi merupakan salah satu layanan bimbingan dan konseling yang memungkinkan siswa dan pihak-pihak yang dapat memberikan pengaruh besar kepada siswa menerima dan memberi informasi yang dapat dipergunakan sebagai bahan pertimbangan dan pengambilan keputusan sehari-hari sebagai pelajar, anggota keluarga dan masyarakat.

Winkel \& Hastuti (2007 : 316) menyebutkan bahwa Layanan informasi merupakan salah satu layanan bimbingan yang meliputi data dan fakta yang merupakan informasi yang harus dicernakan oleh siswa dan mahasiswa sehingga tidak tinggal pengetahuan belaka, tetap menghasilkan pemahaman tentang diri sendiri dalam berhubungan dengan lingkungan hidupnya dan dalam mengarahkan proses perkembangannya.

Layanan informasi merupakan proses bantuan yang diberikan kepada para siswa tentang berbagai aspek kehidupan yang dipandang penting bagi mereka, baik melalui komunikasi langsung, maupun tidak langsung seperti, melalui media cetak maupun elektronik, seperti: buku, brosur, leaflet, majalah, dan internet (Yusuf 2009:80). 
Pemberian layanan informasi merupakan kegiatan pemberian bantuan dari seorang ahli dalam hal ini guru pembimbing kepada siswa baik berupa informasi mengenai pemahaman diri, penyesuaian bakat, minat, pemahaman, cita-cita, pendidikan maupun pekerjaan yang akan dipilihnya di masa depan.

$$
\text { Layanan informasi dapat }
$$

diselenggarakan melalui ceramah, tanya jawab, dan diskusi yang dilengkapi dengan peragaan, selebaran, tayangan foto, film atau vidio, kunjungan ke perusahaanperusahaan. Berbagai nara sumber, baik dari sekolah sendiri, atau dari sekolah lain, dari lembaga-lembaga pemerintah, maupun dari berbagai kalangan di masyarakat dapat diundang guna memberikan informasi kepada siswa. Namun perlu diingat bahwa semua kegiatan hendaknya direncanakan secara matang. Layanan informasi dapat dilaksanakan secara individual, klasikal dan ataupun diselenggarakan secara umum. Dapat juga diberikan secara lisan ataupun seperti jurnal, majalah, dan leaflet.

Surya (1998: 238) menguraikan sumber informasi karir dapat diperoleh dari berbagai sumber seperti Departemen Tenaga Kerja, Perusahaan, Instansi-instansi tertentu baik pemerintah maupun swasta, sumber-sumber kepustakaan, dokumen pejabat tertentu, dan sebagainya.

Bentuk-bentuk Informasi Karir, Bentuk konkret bahan informasi dapat berupa empat macam, yaitu lisan, tertulis, audiovisual, dan disket program komputer (Winkel: 2004: 322).

Ada beberapa bentuk informasi karir yang dicetak menurut Sukardi (1989:42), diantaranya: 1) Career Fiction. Uraian yang berhubungan dengan sesuatu pekerjaan dengan kewajiban, kondisi, sifat pekerjaan serta jenjang kenaikan yang diwujudkan dalam bentuk gambar-gambar berupa pengalaman-pengalaman tokoh cerita. 2) Biografi. Suatu uraian mengenai kehidupan seseorang yang telah berhasil dalam bidang usahanyan dan menggambarkan pula tentang berbagai permasalahannya yang dihadapi dan dalam mempersiapkan dan membina serta memajukan usahanya itu.3) Occupational Monograph. Suatu bentuk informasi yang menguraikan secara luas semua tahaptahap pekerjaan dan mengemukakan pula analisa komprehensif terhadap suatu bidang pekerjaan dan pekerjaan lain yang saling berkaitan. 4) Occupational Brief. Adalah lebih sempit ruang lingkupnya dibandingkan dengan occupational monograph yang menguraikan berbagai jenis spesialisasi dalam satu bidang pekerjaan yang memakai istilah-istilah yang umum. Uraiannya secara umum berbentuk seperti prosa.5) Occupational Abstract. Occupational abstract dapat berbentuk sibuk prosa maupun outline yaitu berupa suatu ringkasan yang padat dan menguraikan tentang satu pekerjaan dalam suatu bidang pekerjaan, disertai dengan kewajiban sifat pekerjaan dalam bentuk istilah-istilah yang umum. 6) Poster On Chart,Suatu bentuk informasi jabatan yang dikemukakan dengan memakai gambargambar, grafik-grafik tabel-tabel dan sebagainya dalam tata warna maupun hitam putih, yang secara langsung menggambarkan informasi pekerjaan, kesempatam, kecenderungan, kualifikasi dan persiapan. 7) Article or Reprint. Suatu bentuk informasi jabatan yang menguraikan mengenai suatu pekerjaan atau seseorang yang melakukan pekerjaan, yang biasanya diuraikan dalam bentuk esai dan dimuat di surat kabar, majalah atau media penerbitan lainnya. 8) Job Series, Job Series biasanya bisa diwujudkan dalam bentuk buku, artikel, yang menguraikan secara luas suatu bidang pekerjaan, dengan memerlukan keterangan singkat dari semua kesepakatan kerja yang ada dalam satu bidang kerja. 9) Recruitment Literature. Suatu informasi promosi yang ditujukan untuk mengerahkan para pemuda dan pemudi untuk memasuki suatu pekerjaan. Disini dikemukakan secara singkat tentang fakta-fakta pekerjaan. 10) Community Survey, Economic, Job Analysis. Suatu bentuk informasi yang mewujudkan 
uraiannya dalam bentuk laporan yang sifatnya komprehensif, statistik dari suatu perusahaan yang ruang geraknya lokal maupun nasional. 11) Business and Industrial Descriptive Literature. Menguraikan satu perusahaan atau usaha tertentu yang menunjukkan ruang lingkup dan kesempatan-kesempatan peerjaan tertentu. 12) Other.Berbagai macam bentuk informasi jabatan yang dinyatakan dengan bentuk- bentuk yang berbeda seperti di atas.

Sukardi (1989: 45) menyatakan bahwa untuk melihat ada tidaknya informasi karir yang memadai dan sesuai dengan kebutuhan ada beberapa kriteria yang bisa dipergunakan diantaranya adalah:1) Ketepatannya. Informasi karir yang diperoleh harus menggambarkan kenyataan saat ini. Konselor harus membandingbandingkan bahan informasi dan dihubungkan dengan perkembangan karir yang ada. 2) Kebaruannya. Informasi karir yang diperoleh harus tepat dan up to date. Bila informasi tersebut masih tepat dan baru, maka informasi karir tersebut masih dapat digunakan dalam pengambilan keputusan karir. 3) Kegunaannya. Informasi karir yang diperoleh digunakan oleh siswa yang berminat ke arah karir yang terdapat dalam informasi tersebut. 4) Menarik pembaca. Informasi karir disajikan dalam kemasan yang menarik, layout yang menyenangkan, ilustrasi dan tata warna yang sesuai dengan selera siswa. Hal ini dilakukan agar siswa tertarik terhadap informasi karir yang diberikan. 5) Menyeluruh. Informasi karir hendaknya meliputi berbagai aspek kehidupan, seperti aspke ekonomi, sosiologis dan psikologis.

\section{Google Classroom}

Google classroom merupakan salah satu aplikasi yang dapat digunakan dalam pembelajaran jarak jauh selama pandemi ini. Pemerintah melalui Kemendikbud menyebut Google Classroom sebagai salah satu platform pembelajaran daring terkait imbauan belajar dari rumah demi mencegah pandemi virus corona COVID-19 di Indonesia. Google classroom adalah layanan web gratis, yang dikembangkan oleh Google untuk sekolah, yang bertujuan untuk menyederhanakan membuat, mendistribusikan, dan menilai tugas tanpa harus bertatap muka. Google Classroom memungkinkan kegiatan belajar mengajar menjadi lebih produktif dan bermakna dengan menyederhanakan tugas, meningkatkan kolaborasi, dan membina komunikasi. Pengajar dapat membuat kelas, memberikan tugas, mengirim masukan, dan melihat semuanya di satu tempat.

Kelebihan dari google classroom dari sisi manajemen kelas google classroom lebih rapi bila dibandingkan dengan kelas lain, di google classroom ada menu "classwork" yang akan mengelompokan file unggulan menjadi dua : file materi dan file tugas. Ketika menu ini dikulik maka kita akan disajikan dengan materi dan daftar tugas yang ada di kelas. Uniknya daftar ini bisa terdiri dari beberapa file yang dikelompokan dalam satu atau atau beberapa kategori :materi pengenalan wordpress. Dalam satu kategori ini kita bisa isi dengan beberapa file materi. Sehingga tidak tercampur dengan file dari kategori yang berbeda. Hal ini memudahkan identifikasi siswa untuk mengetahui ada berapa materi yang harus dikuasai pada kategori kelas yang diikuti, sehingga ketika ada siswa susulan atau yang baru masuk dalam google classroom, siswa tersebut dengan mudah menyesuaikan dan tidak harus kehilangan materi yang disampaikan oleh guru.

Kelemahan Google Classroom yaitu hanya bisa diakses dengan akun google, sebenarnya sama dengan media sosial yang lain, mereka harus log in menggunakan akun yang dibuat di media sosial tersebut. Namun di media sosial lain biasanya sig in bisa memakai akun email dari platform manapun. Sehingga memungkinkan untuk menerima akses pengguna dari kalangan tak terbatas. Sedangkan google classroom hanya bisa diakses oleh pemilik akun google. Hal ini sebagai syarat agai kegiatan 
kelas dengan orang lain, jika kita sedang menggunakan google classroom.

\section{METODE PENELITIAN}

Penelitian ini termasuk penelitian tindakan bimbingan konseling. Populasi penelitian ini adalah seluruh siswa kelas XII SMA Negeri 1 Tarakan. Teknik pengambilan sampel yang digunakan yaitu dengan menggunakan purposive sampling dengan sampel penelitian adalah siswa SMAN 1 Tarakan kelas XII MIPA 3 dengan jumlah siswa sebanyak 36 orang, terdiri dari 16 siswa laki-laki dan 20 siswa perempuan. Penelitian secara keseluruhan dilaksanakan pada tanggal 30 september 2020 sampai dengan 24 oktober 2020 yang bertempat di SMA Negeri 1 Tarakan.. Desain penelitian ini menggunakan model Kemmis dan Mc Taggart, model ini terdiri dari empat komponen diantaranya yaitu: perencanaan, tindakan, observasi, refleksi. Teknik pengumpulan data diperoleh melalui observasi dan hasil pemahaman perencanaan karir yang diperoleh dari tes awal dan tes disetiap akhir pertemuan. Penelitian ini terdiri dari dua siklus, yaitu siklus I terdiri dari $3 \mathrm{kali}$ pertemuan dan siklus II yang juga terdiri dari 3 kali pertemuan. Analisis data menggunakan analisis deskriptif. Data yang diperoleh pada setiap kegiatan observasi dari setiap siklus, dianalisis secara deskriptif menggunakan teknik persentase untuk melihat kecenderungan yang terjadi dalam proses layanan. Instrumen yang digunakan yaitu berupa metode angket dan observasi

\section{HASIL DAN PEMBAHASAN}

Penelitian tindakan bimbingan konseling ini dilakukan dalam 2 siklus untuk menentukan bagaimana meningkatkan pemahaman perencanaan karir melalui layanan informasi karir menggunakan aplikasi google classsrom. Pra tindakan yang dilakukan peneliti adalah untuk menambah keakuratan data yang menjadi latar belakang masalah penelitian ini, Berikut data pemahaman perencanaan karir siswa sebelum kegiatan PTBK :

Tabel 1. Hasil Angket Pemahaman Perencanaan Karir Siswa Sebelum Tindakan

\begin{tabular}{ccccc}
\hline No & $\begin{array}{c}\text { Skor } \\
\text { Perencanaan } \\
\text { Karir }\end{array}$ & $\begin{array}{c}\text { Jumlah } \\
\text { siswa }\end{array}$ & $\begin{array}{c}\text { Persentase } \\
(\boldsymbol{\%})\end{array}$ & Kategori \\
\hline $\mathbf{1}$ & $10-12$ & 0 & 0,00 & $\begin{array}{c}\text { Sangat } \\
\text { Baik }\end{array}$ \\
\hline $\mathbf{2}$ & $7-9$ & 16 & 44,44 & Baik \\
\hline $\mathbf{3}$ & $4-6$ & 13 & 36,11 & Cukup \\
\hline $\mathbf{4}$ & $0-3$ & 7 & 19,44 & Kurang \\
\hline
\end{tabular}

Berdasarkan analisis kondisi awal perencanaan karir siswa sebelum melakukan informasi karir yaitu siswa yang memiliki pemahaman perencanaan karir di kelas XII MIPA 3 ini masih sangat rendah, hanya 16 siswa atau $44,44 \%$ saja yang memiliki pemahaman perencanaan karir, dan masih berada pada skor dengan rentang 7-9. Hal ini karena kurangnya informasi karir yang diterima siswa sehingga siswa belum bisa merencanakan karirnya secara maksimal., selain itu karena kondisi pandemi saat ini sehingga intensitas pertemuan siswa dengan guru BK berkurang. Oleh karena itu pemahaman secara individu harus ditindaklanjuti melalui aplikasi yang melibatkan peneliti secara langsung dalam proses penyampaian informasi melalui google classroom.

Memperhatikan skor yang diperoleh siswa dalam kegiatan layanan informasi karir menggunakan aplikasi google classroom dari pertemuan 1, 2 dan 3 pada siklus I, maka dapat dilihat peningkatan pemahaman perencanaan kerir secara signifikan dan untuk jelasnya dapat dilihat pada Tabel 2 berikut.

Table. 2 Peningkatan Pemahaman Perencanaan Karir Siklus I 


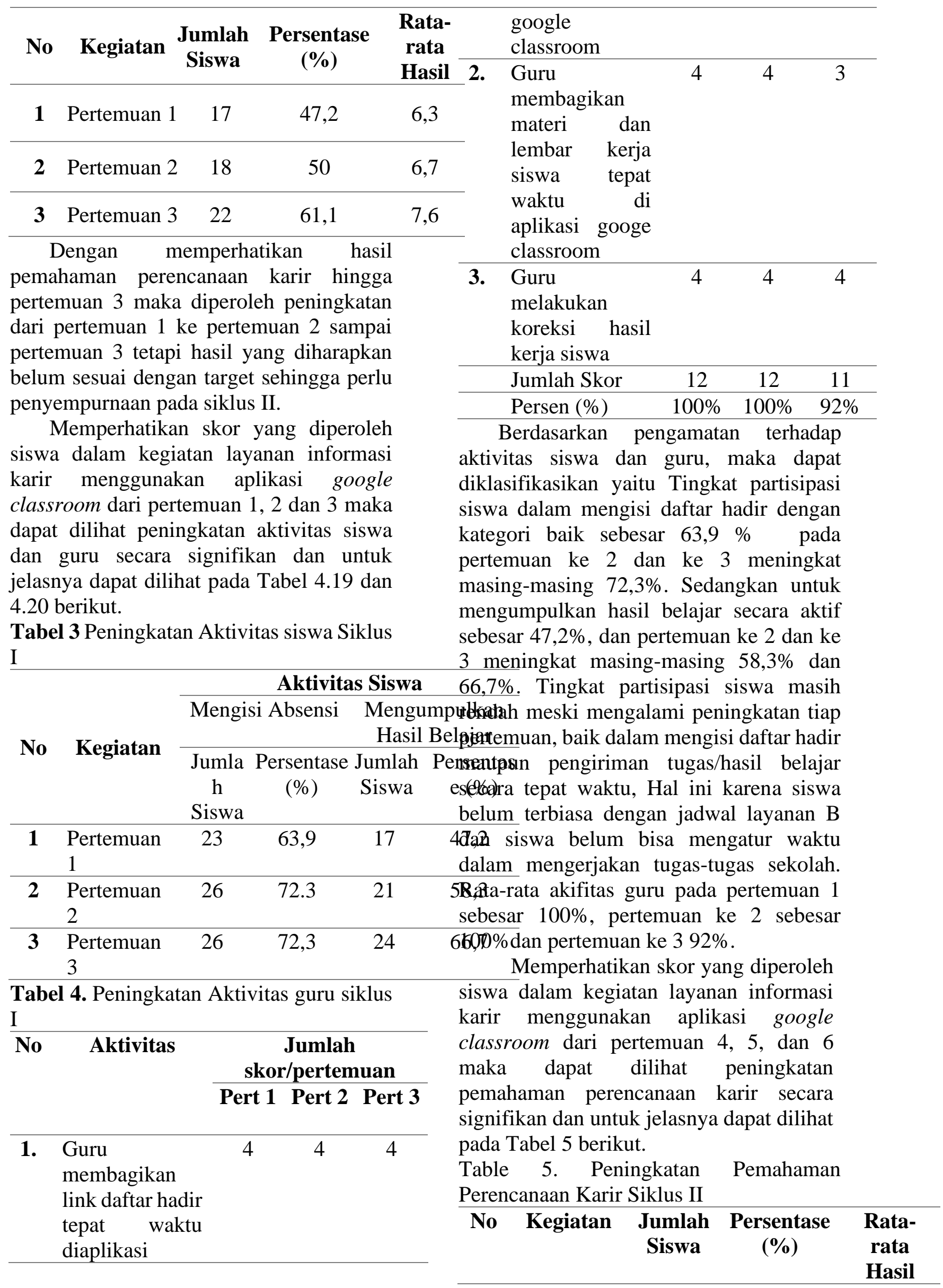




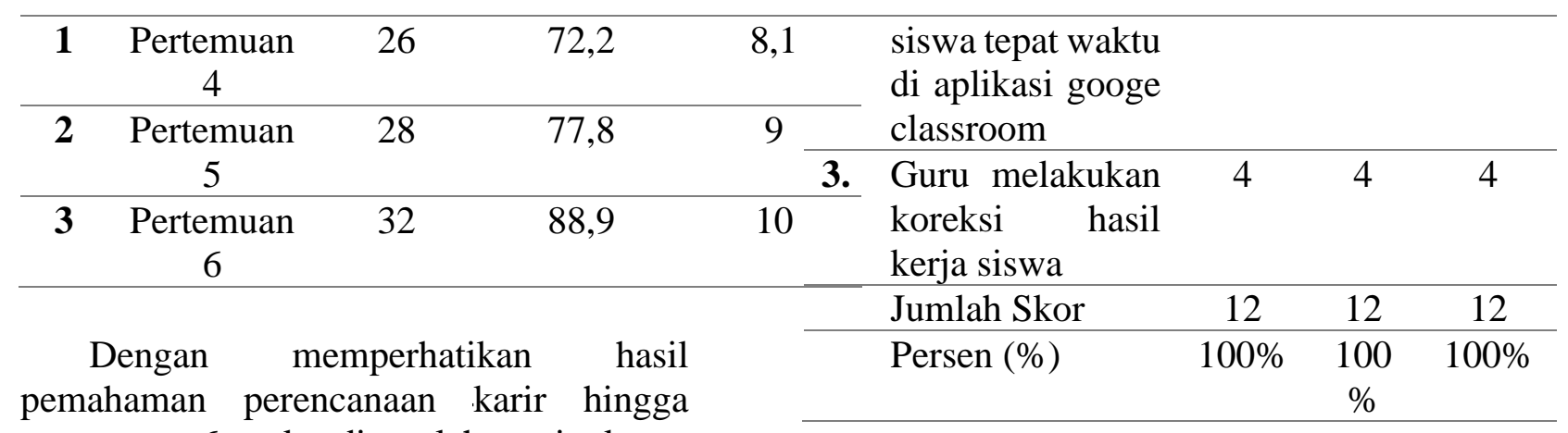

pertemuan 6 maka diperoleh peningkatan dari pertemuan 4 ke pertemuan 5 sampai pertemuan 6 sehingga penelitian dihentikan karena telah terpenuhi indikator keberhasilan penelitian.

Memperhatikan hasil pengamatan dalam kegiatan layanan informasi karir menggunakan aplikasi google classroom dari pertemuan 4, 5 dan 6 maka dapat dilihat peningkatan aktivitas siswa dan guru secara signifikan dan untuk jelasnya dapat dilihat pada Tabel 4.36 dan 4.37 berikut.

Tabel 4.36 Peningkatan Aktivitas siswa Siklus II

\begin{tabular}{|c|c|c|c|c|}
\hline \multirow{3}{*}{ No } & \multirow{3}{*}{ Kegiatan } & \multicolumn{3}{|c|}{ Aktivitas Siswa } \\
\hline & & \multicolumn{2}{|c|}{ Mengisi Absensi } & \multirow{2}{*}{$\begin{array}{l}\text { Mengun } \\
\text { n Hasil } \\
\text { Jumlah } \\
\text { Siswa }\end{array}$} \\
\hline & & $\begin{array}{c}\text { Jumla } \\
\text { h } \\
\text { Siswa }\end{array}$ & $\begin{array}{c}\text { Persentas } \\
\text { e }(\%)\end{array}$ & \\
\hline 1 & $\begin{array}{l}\text { Pertemuan } \\
4\end{array}$ & 32 & 88,9 & 28 \\
\hline 2 & $\begin{array}{l}\text { Pertemuan } \\
5\end{array}$ & 29 & 80,6 & 29 \\
\hline 3 & $\begin{array}{l}\text { Pertemuan } \\
6\end{array}$ & 32 & 88,9 & \\
\hline \multicolumn{5}{|c|}{ Tabel 4.37 Aktivitas guru siklus II } \\
\hline \multirow[t]{2}{*}{ No } & \multirow[t]{2}{*}{ Aktivit: } & & \multicolumn{2}{|c|}{$\begin{array}{c}\text { Jumlah } \\
\text { skor/pertemuan }\end{array}$} \\
\hline & & & Pert 1 Pert & 2 Pert 3 \\
\hline 1. & $\begin{array}{l}\text { Guru } \\
\text { membagikan } \\
\text { daftar hadir } \\
\text { waktu diapl } \\
\text { google class }\end{array}$ & $\begin{array}{l}\text { link } \\
\text { tepat } \\
\text { ikasi } \\
\text { oom }\end{array}$ & 4 & 4 \\
\hline 2. & $\begin{array}{l}\text { Guru } \\
\text { membagikan } \\
\text { materi } \\
\text { lembar }\end{array}$ & $\begin{array}{l}\text { dan } \\
\text { kerja }\end{array}$ & 4 & 4 \\
\hline
\end{tabular}

Berdasarkan pengamatan terhadap aktivitas siswa dan guru, maka dapat diklasifikasikan sebagai berikut: Tingkat partisipasi siswa terlihat mengalami kemajuan, keinginan siswa hadir di classroom hingga $88,9 \%$ pada pertemuan ke 6, demikian juga mengumpulkan tugas mecapai 83,3\%, Aktifitas guru selama pembelajaran baik membagikan daftar hadir, materi lembar kerja siswa dan melakukan koreksi masing-masing mencapai $100 \%$.

Pemahaman Perencanaan Karir siswa

Dari data yang telah dipaparkan di atas

idksil penelitian menunjukkan bahwa Belkajganan informasi karir dapat Persaanangkatkan pemahaman perencanaan k9uiri siswa dan memberikan dampak positif. Hal ini dapat dilihat dari semakin 77̧, diknya pemahaman siswa terhadap perencanaan karir melalui layanan 80,j6formasi karir yang disampaikan peneliti, yakni pemahaman perencanaan karir meningkat dari siklus I hingga siklus II yaitu masing-masing pada siklus I pertemuan pertama hanya 17 orang siswa atau $47,2 \%$ saja yang memiliki pemahaman dan pada siklus II pertemuan keenam meningkat menjadi 33 orang siswa atau $88,9 \%$ memiliki pemahaman secara klasikal serta rata-rata hasil siswapun meningkat dari rata-rata siklus I pertemuan pertama 6,3 meningkat pada siklus II pertemuan keenam menjadi 10 sehingga melampaui kriteria perencanaan karir secara individu yaitu skor 7-12. walaupun masih ada 4 orang siswa atau $11,1 \%$ belum mencapai pemahaman perencanaan karir maka akan ditindaklanjuti dengan melakukan konseling individu atau 
bimbingan kelompok sehingga mampu mencapai pemahaman perencanaan karir.

\section{Kemampuan Peneliti Dalam Mengelola Layanan Informasi karir}

Berdasarkan analisis data, diperoleh hasil pemahaman perencanaan karir siswa terhadap proses layanan informasi karir dengan menggunakan aplikasi google classroom ,dalam setiap siklus mengalami peningkatan. Hal ini berdampak positif terhadap hasil belajar peserta didik yaitu dapat ditunjukkan dengan meningkatnya pemahaman perencanaan karir siswa dari siklus I hingga mengalami peningkatan pada siklus II, yakni dari rata-rata 6,3 pada siklus I pertemuan 1 menjadi 10 pada siklus II pertemuan 6 .

\section{Aktivitas Siswa Dalam kegiatan layanan informasi karir}

Berdasarkan analisis data, diperoleh hasil terkait aktivitas siswa yaitu kehadiran peserta didik dan ketepatan dalam mengumpulkan lembar kerja dalam proses layanan informasi karir menggunakan aplikasi google classroom terdapat peningkatan kehadiran dan pengumpulan lembar kerja siswa dalam layanan informasi karir. Masalah kehadiran dan pengumpulan lembar kerja siswa yang pada awalnya terjadi dapat di atasi oleh peneliti dengan melakukan pendekatan secara personal terhadap peserta didik.

\section{KESIMPULAN}

Berdasarkan tujuan dan hasil analisis data dalam penelitian dengan judul upaya meningkatkan pemahaman Perencanaan Karir melalui Layanan Informasi Larir menggunakan media Google Classroom siswa kelas XII MIPA 3 SMA Negeri 1 Tarakan tahun pelajaran 2020/2021 maka dapat diambil kesimpulan bahwa bahwa terjadi peningkatan hasil pemahaman perencanaan karir siswa melalui layanan informasi karir dengan peningkatan dari 47,2\% pada siklus I menjadi $88,9 \%$ pada siklus II, dengan kehadiran peserta didik pada siklus I hanya $64 \%$ meningkat menjadi $88,9 \%$ pada siklus II, dan ketepatan waktu siswa mengumpulkan hasil belajar pada siklus I hanya 47,2\% meningkat menjadi $83,3 \%$ pada siklus II. Dengan memperhatikan hasil penelitian dengan hasil pemahaman perencanaan karir yaitu 88,9 \% dengan rata-rata hasil pemahaman perencanaan karir individunya mencapai 10 sehingga penelitian dihentikan karena telah tercapai sesuai indikator keberhasilan, walaupun masih terdapat 4 siswa dengan persentase $11,1 \%$. Yang belum memiliki pemahaman perencanaan karir. Siswa yang belum mencapai pemahaman perencanaan karir akan diberikan bimbingan individu dalam waktu berikutnya sehingga diharapkan semua siswa memiliki pemahaman perencanaan karir.

\section{REFERENSI}

Atmajaya, Twi Tandar. (2014). Upaya Meningkatkan Perencanaan Karir Siswa Melalui Bimbingan Karir dengan Penggunaan Media Modul, diakses dari http://journal.uad.ac.id/index.php/PS IKOPEDAGOGIA/article/download/ 4466/2805, pada tanggal 19 september 2020 pukul 19.56 WITA

Farozin, M., dkk. (2016). Paduan Operasional Penyelenggaraan Bimbingan dan Konseling Sekolah Menengah Atas (SMA). Jakarta

Rambe, Rosalina. (2018). Layanan Bimbingan Karir Dalam Meningkatkan Perencanaan Karir Siswa Kelas XI MIA 3 di Madrasah Aliyah Negeri 3 Medan, diakses dari http://menzour.blogspot.com/2016/1 1/makalah-perencanaan-danpelaksanaan.html, pada tanggal 19 september 2020 pukul 19.57 WITA.

Riyadi, Slamet. ( 2016). Materi Layanan Klasikal Bimbingan \& Konseling untuk SMA-MA Kelas XII. Yogyakarta : Paramitra Publishing

Saifuddin, Ahmad. (2018) Kematangan Karir (Teori dan Strategi Memilih Jurusan Dan Merencanakan Karir). Yogyakarta: Pustaka Pelajar 
Sutanto, Ahmad. (2018). Bimbingan dan Konseling di Sekolah Konsep, Teori Dan aplikasinya. Jakarta : Prenadamedia Group 